\title{
Economics Analysis on Excessive Demand of Land Resources in Process of Urbanization
}

\author{
Shuang Qiu \\ Business School China West Normal University \\ Nanchong, Sichuan, 637009 China
}

\begin{abstract}
Land is the foundation of human survival. The sustainable use of land resources is the fundamental guarantee of human survival and development. And the sustainable use of land resources is the basis for sustainable development of social and economic, too. In recent years, with the rapid development of economy and rapid urbanization, the land resources which as carrier of urban space, is more scarce and get into many difficulties. It has restricted seriously the process of urbanization and the sustainable development of urban economy of our Country. Rational and sustainable utilization of urban land resources has become one of the hot issues and widely concerned by people. This paper has discussed about this issue and put forward to some countermeasures and suggestions.
\end{abstract}

Keywords-Economics Analysis; Excessive Demand; Urbanization; Land Resource

\section{INTRODUCTION}

At present, China is in the key period of accelerating development of urbanization. In 2011, the number of urban population in China exceeded the rural population for the first time, and the rate of urbanization exceeded $50 \%$ for the first time, reaching 51.3\%. At the end of 2014, the urbanization rate has reached $54.77 \%^{1}$. The urbanization of our country enters a new stage of rapid development. In 2030, China's urbanization level will be expected to raise to $70 \%$; in addition, the city and the urban population will also be expected to exceed billion.

Along with the urbanization is the urban population, industrial agglomeration and land expansion. As a result, a series of questions were brought: the blind expansion of urban scale, the decrease of available land, the increasing tension of cultivated land, the low level of land intensive use, the low efficiency, the destruction of ecological environment, the degradation of land, the serious damage and so on. Therefore, it is an important issue that how to coordinate the economic growth, urbanization and the rational use of land resources to achieve the optimal allocation of land resources and improve the quality of urbanization.

\footnotetext{
${ }^{1}$ The National Statistics Bureau

Fund project: National social science fund project in general (13BJL010); Scientific research innovation team in China West Normal University (CXTD2013-9);Dr. Start-up fund projects in China West Normal University (09B013).
}

\section{DRIVING FACTORS OF LAND DEMAND INFLATION IN THE PROCESS OF URBANIZATION}

Since the urbanization beginning of 1990s, the urbanization of our country has made great progress. According to incomplete statistics, China has more than 670 large and medium cities; an average annual growth is about $10 \%$. During the period of 2005-2014, the urbanization rate increases by $1.27 \%$ a year, the average annual increase of urban population is about 18-20 million a year.

TABLE I. URBANIZATION RATES IN RECENT DECADE

\begin{tabular}{|l|l|l|}
\hline year & Urbanization rates (\%) & year-on-year growth \\
\hline 2014 & 54.77 & 1.07 \\
\hline 2013 & 53.7 & 1.13 \\
\hline 2012 & 52.57 & 1 \\
\hline 2011 & 51,27 & 3.77 \\
\hline 2010 & 47.50 & 0.91 \\
\hline 2009 & 46.59 & 0.91 \\
\hline 2008 & 45.68 & 0.74 \\
\hline 2007 & 44.94 & 1.04 \\
\hline 2006 & 43.90 & 0.91 \\
\hline 2005 & 42.99 & - \\
\hline
\end{tabular}

The rapid advance of urbanization will inevitably lead to the increase of urban population and the expansion of the urban scale, meaning that the demand for urban construction land is increasing. According to estimates, the rate of urbanization increases by $1 \%$ a year, it needs to transfer 14 million of people, with 2.87 million of acres of land. In the whole process of urbanization, the total demand for land is about 70 thousand of square kilometers, an average annual demand is about 1400 square kilometers. According to the construction of 100 square meters per capita, the country needs to increase a new construction land of about 18002000 square kilometers. In 2050, China's urban construction land area will reach about 120 thousand of square kilometers. [1]

\section{A. The Original Motivation of Enterprises' Pursuit of Profit Maximization}

The enterprises have become important facilitator of city land use in the process of the evolution of the spatial structure. In the pursuit of profit maximization of the original power, the enterprises has been adjusting their economic activities and activity location, has been achieving urban 
land development and utilization by market competition. The urban lands will get reasonable allocation and utilization through the competition of the land price or rent and regulation, resulting in the whole society's industrial revolution and urban land use structure space evolution. The location of Enterprise development pays more and more attention to the land location, land value, competitive ability, land use efficiency and other considerations, in order to obtain a greater cost advantage and competitive advantage.

\section{B. Industrial upgrading and transformation brought by productivity progress}

Industrial upgrading and transformation is not only the result of the productivity progress, but also the main characteristics of urbanization development. The revolution of city industry embodies a change of major city industry from the primary industry to the secondary industry and the service industry and the resulting change of workers in different industries. In the process of the development and evolution of the urban industry by the sequence of 1-2-3, 21-3 and 3-2-1. The types of urban land use change from agricultural land to non-agricultural land, the internal land of the city varies with the industrial layout, showing a clear layer structure, and resulting in the layer structure being from less to more; the spatial structure of urban system transform from simple integration, overall differentiation, and partial differentiation to overall direction, showing a different space form. The change of industrial structure leads to the expansion of urban land and the evolution of urban system spatial structure. [2]

\section{Local Government over-Reliance on "Land Finance"}

Land finance, also named as the second finance, refers to some local governments' reliance on land transfer payments to obtain financial revenue, to maintain the local fiscal expenditure patterns. In fact, in many places, the second finance has already exceeded the first finance, the income from the land transferring fees is far more than the tax revenue, thus forming a land finance in fact. Getting money from the land has become the largest land demand expansion of local governments. According to the State Council Development Research Center, a research report shows that the local land transfer payments net income has accounted for more than $60 \%$ of the government's budget revenue in some places. In 2009, the land premium income of Shenyang, Chengdu, Tianjin, Ji'nan, Hefei, Guangzhou, Dalian, Nanjing and other cities is more than the $50 \%$ of local revenue, including Shenyang even as high as $92.2 \% .{ }^{[3]}$ According to the statistics of Treasury Department, from January to June 2013, 306 cities traded total land transactions of 15493 , land transfer payment is up to $¥ 1130.5$ billion, compared with the same period last year it increased by $60 \%$. Among them, in first half year land transfer payments of Beijing increased by $390 \%$, at the same time Shanghai increased by $277 \%$, Hangzhou had an increase of $504 \%$.Even with the price of housing is depressed, the land transfer price still hit the high of record. According to reports, July 9, 2014, Huangpu District in Shanghai, a parcel of land sold gold floor price has more than $¥ 85$ thousands, creating the new record of a national residential land price. In 2014, 300 cities had a total of 27907 land transactions, land premium reached $¥ 2341.2$ billion, the average rate of growth is $10 \%$ a year. $^{2}$

\section{THE CONSEQUENCES OF LAND DEMAND EXPANSION IN THE PROCESS OF URBANIZATION}

\section{A. The frequent emergence of"empty city" and "ghost city", Urban scale expanding disorderly}

Now the Chinese is in the new unprecedented campaign of "building city", overwhelming. The local government is competing around the town level upgraded and county to the city, the city to the international metropolis development, even to antique city, university city, golf courses, miniature landscape, luxury villas, etc., urban land expanded rapidly.

According to the research institution of national development and Reform Commission, there are 12 provincial capital cities that is said to build metro, 133 out of 144 cities propose to build New city or new district, it has a total of 200 new towns planning and construction, 67 among 161 county-level cities plan to build construction of new towns, city planning covers an area of 6105 square kilometers, it is equivalent to more than half of the existing urban built-up area. ${ }^{3}$ And the construction of the metro is completely pie style expansion in urban planning, exceeding pervasively the reality in the terms of planning area and population, it is also beyond the law of economic and social development. From 2000 to 2010, China's urban area expanded by $83.41 \%$, but the urban population increased only by $45.12 \%$, the growth rate urban land use to growth rate of population is 1.85 , being far higher than the internationally recognized reasonable threshold value of 1.12 . It resulted in a large number of "empty", "necropolis", "ghost town", from the Ordos in the Kangbashi District, Liaoning Dong Dai River District, Yingkou camp East Metro, Hefei Binhu New Area, Changzhou southern part of the city, Shiyan East Metro, Xiantao Nancheng district to Yunnan Chenggong New area, and Shenzhen Daya Bay, Sanya, Xiamen etc. "Empty city", "Dead city" and "ghost city" are vividly call for the city that with high vacant rate, low rate of occupancy rate, and the dark night. [4]

\section{B. The low intensive utilization of land, seriousness of vacancy and waste}

Because land use and management mechanism are not perfect, the phenomenon of unreasonable land use and abuse is still very serious, resulting in urban land being idle and wasting seriously, and the degree of intensive use being very low.

The survey shows that the $4 \%-5 \%$ of urban land in our country is in idle state, about $40 \%$ is used inefficiently. ${ }^{[5]}$ Data shows that urban built-up area have about $17 \%$ of the

\footnotetext{
${ }^{2}$ China Index Academy. In2014, transaction information of 300 urban land market in china.

http://www.askci.com/chanye/2015/01/05/1020385f9p_all.shtml ${ }^{3}$ http://finance.china.com.cn/news/dfjj/20130905/1790454.shtml
} 
existing land idle. The edge of city, especially combination of urban and rural areas, has a vacant space, vacant land, flower arranging, and farmers Housing lack of unified management, resulting in a waste of land. In rural areas, the vacancy and extensive use of construction land is also very prominent. In 2010, rural residential land is close to 190 thousand of square kilometers, 2.4 times the same period of urban construction land. After clean-up and rectification, up to May 31, 2013, the country has a total of 35.5 thousand of hectares of idle land. In 2014, the Ministry of land resources carried out special supervision, cleaning out the land granted but not supplied of 13000 thousand of acres and 1000 thousand of acres of idle land. ${ }^{4}$ The rate of china's urban industrial land area is generally over $25 \%$, some even more than $35 \%$, far higher than the level of foreign $15 \%$. The rate national industrial project land is only $0.3 \%-0.6$, while the rate in the developed countries and regions is general over 1.

\section{The layout and structure of land use are not reasonable, and the urban construction is convergent}

According to the survey of 55 cities in our country, the land occupied $37 \%, 27.5 \%$ of the industrial land. But according to state regulations, the use structure of rational urban land is the $40 \%-50 \%$ living space of land, the industrial land occupies $10-15 \%$, the road square is $8 \%-15 \%$, and the green space is $8-15 \%$. It shows that the proportion of the city's industrial land in China is $10 \%$ higher than planned, while land for residential, commercial services and other life is $3 \%$ to $10 \%$ lower. It not only exceeded far the developed countries and regions, but also many developing countries. This caused serious "urban disease" such as waste of land assets, low output rate of land, traffic congestion, Poor quality of the environment, etc. [6] At the same time, due to the duplication of construction, the structures of China's cities appear to converge. In the transportation infrastructure construction, the construction of roads, railways, ports, airports and other had no overall consideration, comprehensive coordination, coupled with the fragmentation and disordered competition of local governments, ,resulting in the phenomenon of repeated construction being serious and inefficient use of land. For example, in Jiangsu Province, along the Yangtze River in the 300km range, almost every city along the river has or is building their own ports, causing a lot of waste of land. Nanjing following about 300 kilometers of the Yangtze River along the construction or under construction of the 10000 ton terminal has 110, the most dense section of the following 40 kilometers has on average one terminal per kilometer. The efficiency of use is low. For instance, the design of the Changzhou's freight transportation capacity is 248 ton, but some years can only accomplish 6 ton. ${ }^{5}$

\section{The increasing accumulation of local government debt and the increase of financial risk}

Up to the end of June 2013, the national local government has the responsibility to repay the debt balance

\footnotetext{
${ }^{4} \mathrm{http} / / /$ www.yicai.com/news/2015/01/4064065.html

${ }^{5}$ http://finance.sina.com.cn/roll/20050621/0914140855.shtml
}

of $¥ 10.89$ trillion, plus contingent liabilities, local government debt amounted to $¥ 17.9$ trillion. Up to the end of 2014, the debt balance of national local government has reached $¥ 15.4$ trillion, and contingent liabilities $¥ 8.6$ trillion. Annual debt interest burden reached $¥ 600$ to $¥ 700$ billion. The debt obviously exceeded the current fiscal revenue, the deficit is the normality of relationship between government debt and fiscal revenue. The bonds issued by cities exhibited a scale of explosive growth, in 2012 the issue of bonds is more than $¥ 800$ billion, an increase of more than $130 \%$. According to the estimate, the public investment scale of local government incurred by urbanization will reach $¥ 30$ trillion in the end of the 12th Five-Year Plan. ${ }^{6}$

\section{THE PATH OF ALLEVIATING DEMAND EXPANSION AND OPTIMAL ALLOCATION OF LAND RESOURCES}

\section{A. Elimination of land finance, optimizing the performance evaluation system of cadre}

Firstly, it needs to reform the public financial system. Establishing a diversified public investment mechanism of urban, and reducing the motivation of local government seeking out extra-budgetary revenue eliminate the pulse of local government's transfer of land from the economic mechanism. Secondly, it requires to change the monopoly right of construction land of local government, and establish a unified use right market in urban and rural land. Thirdly, it also needs to improve the structure and performance evaluation mechanism of local governance. With the government function orientation from "building government" to "service oriented government", it requires to reform the performance evaluation system based on GDP index as the core, to establish a local governance mechanism which is responsible for the people.

\section{B. Optimize the land structure and layout, improve the land use efficiency}

It must gradually improve and optimize the use structure of urban land, and rationally organize use function of land under the guidance of the planning by means of economic levers of the differential land rent. According to the "Best to best use" principle, it needs to gradually realize the industrial land of city center zone by "from two into three", "optimizing two and thriving three", the part plants of center zone migrates to free up land to develop trade and industry, service industry and the tertiary industry. In the adjustment of land use structure, the comprehensive benefit of land use should be considered, and the social benefit and ecological benefit of land use need to be enhanced.

\section{Further improve the policies and regulations, strengthen urban land management}

First, it needs to regulate and use the land in accordance with the law, and to increase the supervision of the land sector and the law enforcement efforts imposed on the land sector. Secondly, it needs to implement the dynamic

\footnotetext{
${ }^{6}$ http://finance.sina.com.cn/china/20150830/090323118719.shtml
} 
management of urban land, strictly restrict the land use in the planning and control of strict land use control, and strictly implement the a book and two card system of construction land. Thirdly, it must straighten out the management system of land, establish and improve the reserve system of land acquisition. Fourth, it must improve the bargained transfer of urban land, the relevant laws and regulations of transfer. Fifth, we must strengthen the management and service of the rural land contract management right circulation, establish a perfect market in rural contracted land use rights, strictly approve and manage rural homestead, and explore and establish the moving Mechanism of Rural Homestead land.

\section{Construct the constraint mechanism of urban construction financing, keep away land financing risk}

Firstly, it requires to establish and improve the legal norms of local government debt financing management as soon as possible. Secondly, establish a unified national management system of the government debt financing. Change the "decentralization" management mode of government debt quickly. Thirdly, establish the scale control of debt financing and risk warning mechanism, real-timely analyze the trend of government debt. Fourth, it must improve the information disclosure system of local government debt financing. In addition, it must also establish a strict system of accountability of government debt and the evaluation system of government debt. [7]

\section{CONCLUSION}

Land urbanization is an important content and external manifestation of urbanization. When the population size, industrial development and urbanization are not compatible, it is inevitable that the city is crowded, a large number of arable land is occupied, the idle land waste, ecological environment damages. It must correctly handle the contradiction between urban construction land demand and land sustainable development, solve the problems of urban construction funds and land financial problems, intensive and economical use of real urban land, maintain the good relation between urbanization and land resources, to ensure the rapid and stable development of China's urbanization process, and promote comprehensive, healthy and sustainable development of economy and society.

\section{REFERENCES}

[1] [1]Lu Xinhai et al. Some problems of sustainable utilization of land resources in the process of urbanization [J]. China real estate, 2013(5):16-17.

[2] [2]Guo Rui, et al. Research on the sustainable use of urban land in the process of urbanization [J].Social Sciences, 2006(9):65-66.

[3] [3]Zhang Weichen. "Land finance" thinks about again [J]. China land, 2011(3): 18 .

[4] [4]Lin Hua. China's property market puzzle in empty city [J].Real estate information of China, 2010(9):49

[5] [5] Li Yixue, etal. Research on the Countermeasure of Sustainable Utilization of urban land in China [J]. Journal of Shandong Agricultural University, 2003(3):388-392.

[6] [6]Liu Xiaoping. Study on the protection of cultivated land in urban sustainable use. Journal of Hunan City University, [J].2005(3):83.
[7] [7]Chen Zhe. Draw lessons from international experience to improve the risk control mechanism of local government debt financing [N].Financial Times,2013.7.29. 